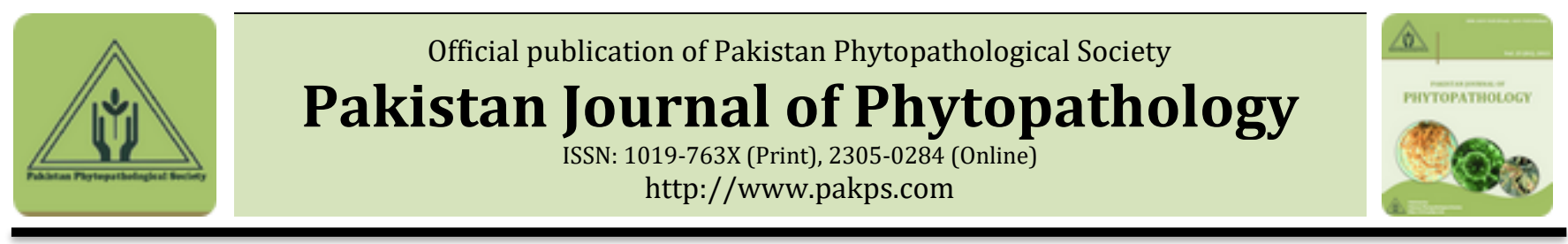

\title{
INFLUENCE OF BT. GERMPLASM ON BACTERIAL BLIGHT DISEASE OF COTTON IN PAKISTAN
}

\author{
${ }^{a}$ Muhammad Sajid*, bAbdul Rashid, aMuhammad Abid, cHumaira Jamil, dMuhammad R. Bashir, \\ eZahid M. Sarwar, a Rashida Perveen, a Sobia Chohan \\ aDepartment of Plant Pathology, Bahauddin Zakariya University, Multan, Pakistan. \\ ${ }^{b}$ Department of Plant Pathology, University of Agriculture, Faisalabad, (ORIC), Pakistan. \\ ${ }^{c}$ Department of Plant Breeding and Genetics, University of Agriculture, Faisalabad, Pakistan. \\ ${ }^{d}$ Oilseeds Research Institute, Ayub Agriculture Research Institute Faisalabad, Pakistan. \\ ${ }^{e}$ Department of Plant Pathology, Bahauddin Zakariya University Multan, Pakistan.
}

\section{A B S T R A C T}

In present research assessment of disease incidence was made between Bt and Non-Bt cotton against bacterial blight disease. Experiment was carried out in natural environmental conditions on twenty eight varieties/advance lines. Findings of the experiments depicted more disease incidence on Non-Bt varieties viz., Non Bt-FH 901 (41.7-43.4\%), Non Bt-MNH 496 (47.6-49.5\%), Non Bt-FH 1000 (48.6-51.2\%), Non Bt-FH 207 (54.5-57.5\%), Non BT-N 112 (54.756.3\%), Non BT-FH 942 (55.7-59.5\%), Non BT-MNH 6070 (61.5-64.7\%), Non Bt-FH 941 (63.4-61.6\%), Non BT-N 814 (70.4-71.3\%), Non Bt-FH 900 (74.7-77.4\%), Non Bt-ANMOL (74.8-76.8\%), Non Bt-FH 2015 (78.5-80.6\%), Non BT REDACOLA (81.5-79.6\%) and Non BT-C 26 (83.3-85.6\%) while BT varieties BT-S-78 (25.8-26.7\%), BT-Z-33 (26.722.2\%), BT-786 (28.6-31.5\%), BT-A-ONE (28.8-26.5\%), BT-282 (30.5-27.6\%), BT-886 (33.5-35.3\%), BT-3701 (38.336. \%), BT-SPECIAL (38.4-34.6\%), BT-802 (41.3-43.4\%), BT-92 (41.4-44.4\%), BT-131 (43.8-41.7\%), BT-905 (44.642.3\%), BT-SUPPER (45.6-46.8\%) and BT-121 (48.6-52.4\%) showed varying response respectively. Hence, concluded that difference/variability in the resistant sources is present in Pakistan against the disease among BT varieties as compared to Non-Bt.

Keywords: Blight, Xanthomonas citri pv. malvacearum, resistant, Varietie, Bacillus thuringiensis

\section{INTRODUCTION}

Cotton (Gossypium hirsutum L.) belongs to Malvaceae family is the backbone of the national economy of the country contributing $1.0 \%$ in GDP and $5.1 \%$ in agriculture value addition. During 2015-16, the cotton crop was sown on an area of 2.917 million hectares with the production of 10.074 million bales in Pakistan (Mishra and Ashock, 2001). Its present area, production, and yield in the world showed that Pakistan is the fourth largest producer of cotton after China, USA, and India (Hanif and Jafri, 2008). The quality of cotton and yield is

Submitted: March 19, 2018

Revised: July 19, 2018

Accepted for Publication: December 19, 2018

* Corresponding Author:

Email: sajid1694@gmail.com

(C) 2017 Pak. J. Phytopathol. All rights reserved. disposed by biotic and abiotic factors, among biotic factors bacterial blight disease is a potential threat to the cotton caused by Xanthomonas citri pv. malvacearum (Xcm) (Vauterin et al., 2000). The disease causes severe losses by reducing photosynthetic activity and destroying the chlorophyll content in leaves and stem. Losses are not as much when only leaves are infected but when stem lesions are formed, the losses may be as high as 90\% (Singh et al., 2007). Type of cultivars, the age of the crop plant and type of infection are major factors for the spread of disease (Mishra and Ashock, 2001). The bacterium survives in the field on plant debris as primary inoculum that enhances the inoculum density and consequently disrupts the initial germination of seedlings (Mohan, 1983). The pathogen attaches to the leaf surface of cotton, enters through open stomata or wounds and 
causes symptoms in susceptible plants leaves and bracts. Angular leaf spot' dark green, water-soaked angular lesions ( 1 to $5 \mathrm{~mm}$ ) appeared on the leaves, especially on the undersurface. The best way to combat with this disease is the cultivation of resistant varieties/ advanced lines because this is the most efficient and eco-friendly approach for the management of this disease. The current research was conducted to verify the source of resistance between BT and Non-BT cultivars/ advances lines against the bacterial blight of cotton from existing varieties under natural field conditions.

\section{MATERIALS AND METHODS}

Evaluation of Cotton Germplasm: To find out genetic resource against bacterial blight disease, the nursery was sown in the research area, Department of Plant Pathology, University of Agriculture Faisalabad, during Table 1. Brinkerhoff disease rating scale for recording bacterial blight of cotton (1977).

\begin{tabular}{llll}
\hline Sr\# & Disease incidence (\%) & Description & Response \\
\hline 1 & 0 & Immune & I \\
2 & $1-10$ & Highly Resistant & HR \\
3 & $11-20$ & Resistant & R \\
4 & $21-50$ & Moderately Resistant & MR \\
5 & $51-70$ & Moderately Susceptible & MS \\
6 & $71-80$ & Susceptible & S \\
7 & $<80 \%$ & Highly Susceptible & HS \\
\hline
\end{tabular}

Disease incidence was calculated by using following formula.

\section{STATISTICAL ANALYSIS}

Disease incidence $(\%)=\frac{\text { No. of infected plants }}{\text { Total No. of plants }} \times 100$

The collected data was subjected to analysis of variance (ANOVA) by using SAS software version 8.1. Means were compared by using the Fisher's least significant differences (LSD) at $P=0.05$.

\section{RESULTS}

The symptoms appeared in the form of water soaked lesions were formed as a result of pathogen attack. With the passage of time spots became dark brown and extent on the ventral surface of young leaves. Screening of cotton germplasm against bacterial blight showed highly significant results under field conditions specifically significant difference was perceived among Non-Bt cotton germplasm in terms of disease incidence. It was clearly examine that ratio of disease incidence was more in Non Bt varieties i.e. Non BT-N 112 (54.7- the season of April 2011 and 2012. BT and Non-Bt seeds of 28 cotton germplasm were collected from Central Cotton Research Institute (CCRI) Multan, Ayub Agricultural Research Institute (AARI) Faisalabad and Department of Plant Breeding and Genetics (PBG) University of Agriculture Faisalabad (UAF). Sowing was done through dibbler method by maintaining distance $\mathrm{R} \times \mathrm{R}=30 \mathrm{~cm}$ and $\mathrm{P} \times \mathrm{P}=75 \mathrm{~cm}$ respectively. The seeds were neither treated with chemicals and nor given acid delinting to enhance primary infection of the disease. Each variety was replicated three times under Randomized Complete Block Design (RCBD). A line of highly susceptible variety i.e. S-12 was sown as a spreader to make the most of the inoculum density under natural conditions. Data regarding disease incidence was collected on a weekly basis by using Brinkerhoff (1977) disease rating scale (Table 1). 56.3), Non BT-C 26 (83.3-85.6), Non BT-MNH 6070 (61.5-64.7), Non BT-N 814 (70.4-71.3), Non BT-ANMOL (74.8-76.8), Non BT-FH 942 (55.7-59.5), Non BT REDACOLA (81.5-79.6), Non Bt-FH 900 (74.7-77.4), Non Bt-FH 1000 (48.6-51.2), Non Bt-FH 901 (41.743.4), Non Bt-FH 207 (54.5-57.5), Non Bt-FH 941 (63.461.6), Non Bt-FH 2015 (78.5-80.6), Non Bt-MNH 496 (47.6-49.5) as compared to Bt varieties i.e. BT-S-78 (25.8-26.7), BT-786 (28.6-31.5), BT-886 (33.5-35.3), BT-3701 (38.3-36.3), BT -282 (30.5-27.6), BT-92 (41.444.4), BT-Z-33 (26.7-22.2), BT-A-ONE (28.8-26.5), BT802 (41.3-43.4), BT-905 (44.6-42.3), BT-131 (43.841.7), BT-121 (48.6-52.4), BT-SUPPER (45.6-46.8) and BT-SPECIAL (38.4-34.6). The graph shows that during both years, disease incidence was more in Non-Bt cultivars/varieties as compared to BT. 


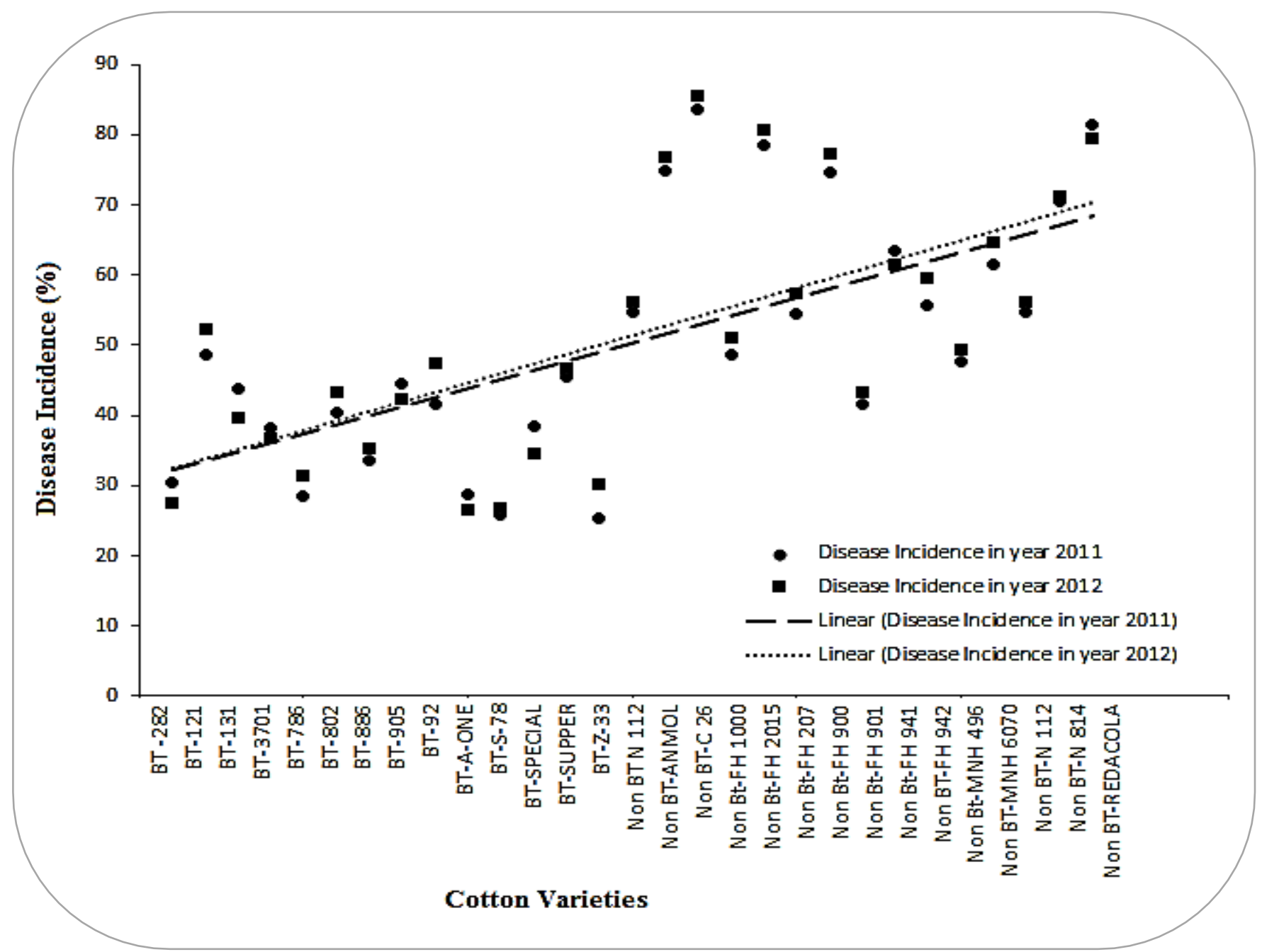

\section{DISCUSSION}

Cotton is an important cash crop of Pakistan and is playing an important role in our GDP. It is vulnerable to a large number of biotic and abiotic factors among them insect pests and diseases play a vital role. During the current research Bt. and Non Bt. germplasm of cotton was evaluated against their response towards the disease in the natural environmental conditions. The results show a true picture of the biological mediated management of the disease by the naturally occurring bacterial resistance and its synergistic effect in suppressing the disease under natural filed conditions. It was first attempt in this respect to evaluate the Bt. and Non Bt. germplasm against blight disease of cotton caused by the bacteria. Our results showed that water soaking was the promising symptom on leaves of the cotton plants formed in response of the disease followed by the dark brown spots extending towards the ventral surface of young leaves and destroying the photosynthetic area of the leaves and causing the reduction in the yield of the crop. Identification of resistance sources of cotton against bacterial blight proved a significant difference among Bt. and Non-Bt cotton germplasm in terms of disease incidence. It is obvious from the results that Bt. germplasm possess the resistance against the disease due to the induced resistance by the bacillus specie or may be due to the synergistic effect. BT cultivars prove themselves resistant offering the most economical means of controlling bacterial blight. Khan (1996) described except for some exotic lines immune to all the races of $X$. citri pv. malvacearum, none of the available commercial varieties were found to be resistant to the bacterial blight. As a result of this study, the selected resistant varieties can be used in the breeding program as a source of resistance and if these resistant varieties possess the entire required agronomic yield attributes, these can also be introduced at the commercial level. 


\section{REFERENCES}

Hanif, M. N. and S. K. Jafri. 2008. Financial Development and Textile Sector Competitiveness. South Asia Economic Journal, 9: 141-158.

Kamal, M. and Q. Naim. 1983. Final report of the scheme on investigation of boll rot of cotton. Agriculture Research Institute Tandojam: 20.

Khan, M. 1996. Relationship of Xanthomonas campestris pv. malvacearum population to development of symptoms of bacterial blight of cotton. Pakistan Journal of Phytopathology, 8: 152-155.

LA, B. 1977.Bacterial blight of cotton. FAO Consultant Report of Pakistan 73/026. FAO (UNO). Rome, p. 11.

Mehta, Y. R., C. Bomfeti and V. Bolognini. 2005. A SemiSelective agar medium to detect the presence of
Xanthomonas axonopodis pv. malvacearum in naturally infected cotton seed. Fitopatologia Brasileira, 30: 489-496.

Mishra, S. and K. Ashok. 2001. Assessment of yield losses due to bacterial blight in cotton. Journal of Mycology and Plant Pathology, 31: 232-233.

Mohan, S. 1983. Seed transmission and epidemiology of Xanthomonas campestris pv. malvacearum, cotton Seed Science and Technology, Netherlands.

Singh, A., S. Srivastava and M. Akram. 2007. Studies on bacterial leaf blight of cotton (Gossypium spp). International Journal of Sustainable Crop Production, 2: 25-29.

Vauterin, L., J. Rademaker and J. Swings. 2000. Synopsis on the taxonomy of the genus Xanthomonas. Phytopathology, 90: 677-682. 